\title{
The Evaluation of Music Department Students of Institut Seni Indonesia Yogyakarta in Modes Identification
}

\author{
Peter Angga Branco De'Vries Mau ${ }^{1}$ dan Prima Dona Hapsari ${ }^{2}$ \\ Program Studi Seni Musik, Fakultas Seni Pertunjukan, Institut Seni Indonesia Yogyakarta
}

\begin{abstract}
ABSTRAK
Evaluasi Pemahaman Mahasiswa Jurusan Musik Institut Seni Indonesia Yogyakarta dalam Mengidentifikasi Modus. Modus merupakan sebuah konsep pemikiran musikal yang digunakan sebelum tahun 1600an. Setelah tahun 1600 (kira-kira era Barok) sistem modus berubah menjadi sistem tonalitas mayor-minor yang kita kenal hingga saat ini. Musik akan selalu berkembang sesuai dengan berjalannya waktu, hingga dalam kenyataannya banyak komposer musik yang menyematkan kembali modus ke dalam karya musiknya untuk membangun nuansa tertentu. Sebagai cendekiawan musik, mahasiswa Musik ISI Yogyakarta juga memperoleh bekal materi mengenai modes dalam teori musik, teori bentuk musik, dan lain sebagainya, namun pola berpikir secara tonalitas nampaknya membuat masih banyak yang belum mampu mengidentifikasikan modus jika diperdengarkan karya yang memuat modus. Penelitian ini menunjukan berapa banyak mahasiswa Musik ISI Yogyakarta yang tidak dapat mengidentifikasikan modes ketika diperdengarkan karya musik yang mengandung modus.
\end{abstract}

Kata kunci: modus; identifikasi modus; modalitas; tonalitas

\begin{abstract}
Modes in the modality concept are musical thinking that was used before the 1600s. After the 1600 s (Baroque Era), the concept of modes changed into a contrasting concept called tonality (majorminor) and still exists today, in our era. Musical knowledge evolves along with technological advances, but so many composers today use the concept of modes to give another nuance and interpretation in their musical works. As academic musicians, indeed, the Music Department of Institut Seni Indonesia Yogyakarta students have received the concept of modes in several subjects, such as musical theory, musical structure and style, musical analysis, etc. However, the tonality concept that is always used by typical academic musicians today makes the concept of modality becomes so hard to identify when the musical work containing modes is being heard. The research shows us the numbers of students of the Music Department of ISI Yogyakarta who are both able and unable to identify the musical work containing the modes.
\end{abstract}

Keywords: modes; modes identification; modality; tonality

\section{Introduction}

To comprehend the Western musical evolution, we must consider what may occurr in ancient civilizations. Ancient Greece was the primary civilization that developed not only in the aesthetics aspect but also the musical system that is still used today in the West (Torres, 2021).
The function of the music in this era cannot be separated from the religious activities. After the era of ancient Greek, the function of music was classified into two musical areas, music for the religion activities, and music for non-religion activities called secular music - it was proven in 12th century the historian who found a script of "Golliard", a work of secular music along with the

1,2 Correspondences: Program Studi Seni Musik, Fakultas Seni Pertunjukan, Institut Seni Indonesia Yogyakarta, Jalan Parangtritis Km.6.5 Yogyakarta. E-mail: peterdevriesproject@gmail.com and dona.hapsari@gmail.com; HP. 085726803366 and 08122763884. 
religious music that was existing before (McNeill, 2002). In this Modern Era, both religious or secular music have no significant distinction if we try to analyze by the musical style, structure, genre, even the instruments.

Before 1600s, the music concept have a basis that used modallity and triads. The music in 9th to 14 th century was not based on major or minor scale, but it used the modes scale. The name of modes was taken from Greek theory. After 1600s (Baroque Era), the concept of modes changed into a contrast concept called Tonality (major-minor) and became a new standard in musical thinking of the composer until today (Stein, 1979).

In Western music, a melody relates to a "key" as the center of a scale. Music is often classified as in a major or minor key, but within a scale that defines a major key, emphasizing different notes as the tonic yields different "modes" (Bostwick et al., 2018). The music that we heard today use the concept of tonality, substitutes the modality concept, the reason is the tonality can describe the modality simpler. But in fact, today's compositions based on modality are found in the modern musical genre like jazz, electronic music, even the film soundracks in which the diatonic modes are traditionally introduced as derivatives of the parent major scale (Terefenko, 2017). The resurgence of modality told us implicitly that it has many reasons why this concept is shown today. In the research area we can find many researches about analyzing and identifying based on modality, for instance a research about makam (traditional Turkish classical music) which can be identyfied by the modality concept (Birson \& Erdoğdular, 2021).

As scholars, students of Music Department of ISI Yogyakarta get their musical theory knowledge better than the other musicians outside the academic area. The musical content is not only discussed from its theory and rules, but it is always discussed from many perspectives, such as philosophy, playing the instrument, and hearing as a practical approach, and so on.

One of the most important in music is solfegio or ear trainings. It has three core indicators : first, hearing and remembering the rhytm, and also writing down the rhytm and re-voicing it.
Second, hearing and remembering melodies, and also writing down the melodies and re-voicing it, the last indicator is primavista (sight singing) skill (Sulasmono, 2013). The three indicators above have been taught in Music Department ISI Yogyakarta, and by this fact, indeed, the content of modes is easy to analyze and identify for the scholars like Music Department Students.

Refering to the musical theory subject in the academic field, the topics of modality and tonality are always taught as the basic knowledge to the students, unfortunately, these topics are only served in theory, it means the students have no empirical knowledge, such as hearing the modes or hearing the distinction of tonality, and modality concept. These facts make the researcher has a skeptic question about the identifying ability of the Students of Music Department, ISI Yogyakarta if they are heard the musical works containing the modes. By the observation and empirical knowledge from the researchers, the practical activity of music hearing in Musical Department ISI Yogyakarta only focuses on the basic solfegio lesson which refers to sing scales, intervals, and melodic exercises with sillaby zolmization (Hidayat et al., 2018). It means that the lesson to identify the big picture of each mode has never been taught before.

A journal entitled "Modality-Resurgence of Musical Thinking" from Josef Veres (Department of Music Constantine the Philosopher University in Nitra, Slovakia) stated that during 19th century, the European musical culture degraded in the tonal harmony system and indicated the use of new musical idiom. Music compositions in this era look contrary with the tonal system paradigm, for which many composers use modality approach as their preference on their works (Veres, 2017). Another evidence about the resurgence of modality comes from Luis Antonio Sanchez's research that use modality perspective to analyze the musical work from José Moncayo, using the Bella Bartók's term about polymodal diatonicism (Sanchez, 2018).

A book entitled "Music and TwentiethCentury Tonality: Harmonic Progression Based on Modality and the Interval Cycles" from Paolo Susanni and Elliott Antokoletz becomes a guide to explore this research because it discusses the 20th 
century composers' thought, and how they analyze their own folk music with the modality approach even ignoring the perspective of tonality (Susani \& Antokoletz, 2012).

The fundamental reason of this research is based on a phenomenon of modes identifying in the Music Department, ISI Yogyakarta as a sample of academic musicians circle. Refering to the researcher's thesis entitled "A Pedagogical Guide for Teaching Diatonic Modality in the Curriculum of the College Music Theory", it has supported this research's background. It is stated that generally the hand books of music theory in graduate programs only discuss the modality topics from its structure and musical scale without a deeper analysis and the application. Another gently statetement said that if the topics of modality are discussed from the theoretical perspective only, then the music students on graduate degree will not understand the use of modes in practical activities (An, 2019).

\section{Research Methods}

This research uses a quantitative approach to describe the results (by percentages) from the evaluation of the Music Department students of Institut Seni Indonesia Yogyakarta on modes identidying. According to Creswell, the quantitative research is as an effort to investigate the problem. The research problems are what underlies the researcher to take data and determine variables, and which are then measured by numbers so that analysis can be carried out in accordance with applicable statistical procedures. As for the purpose of conducting quantitative research, none other than helping in drawing conclusions or assisting in generalizing the right predictive theory (Awwaabiin, 2021). The methods in this research use descriptive method by selecting the samples of 2015 and 2016's students from all Music Programs in the Department of Music. The aim of descriptive method is to describe a phenomenon and its characteristics, then it concerned with what rather on how or why something which has happened (Nassaji, 2015). The data was collected qualitatively, but it was analyzed quantitatively using percentages, and visualized by pie and bar diagrams.
Researcher uses simple random sampling technique for students in four programs of Music Department, Institut Seni Indonesia Yogyakarta. The definition of simple random sampling proposed by Sugiyono, it takes sample members from a population randomly without regard to the existing level in the population (Sugiyono, 2017). The quantity number of the students who became the sample was that of $10 \%$ from the population. From the sample they were be categorized into two groups, the music students who know modes and those who do not know. From the percentage of students who know about modes, they were tested their hearing ability with nine pieces of classical music works, modern music works, and film music composition containing modes. By testing the hearing ability, it informed the result of students who know and do not know modes as an identifying challenge. The result of this test is as the research conclusion.

This resarch also use the hearing method called solfegio to test the participant as the sample to identify the musical works that contain modes. There are two focuses on solfegio lesson method, i.e. the sight reading and ear training, but this research only use the ear training concept as an exercise of hearing ability or musical acuity, both rhythmic and notation accuracy (Benward, 1989).

\section{Results and Discussions}

After deciding the population taken from four programs in Music Department of ISI Yogyakarta, researchers took 31 respondents by simple random sampling to fill out the questionnaires about their understanding of modes. The specific (yes/no) question restricted the answer of the respondents. The results of the questionnaire is representated by the pie diagram in Figure 1. 83.87\% of Music students know about the modes, and $16.13 \%$ do not know about them. Data on four Programs in Music Department is provided in Figure 2.

Based on the bar chart in Figure 2, the students said that they have received the discussion about modes, the programs of Bachelor on Music was at $45.16 \%$, Bachelor on Music Pedagogy was at $19.35 \%$, and 9,68\% for both Bachelor on Music 
Compositition and Vocational Program of Music Performance. The exploration was continued by finding out the degree of comprehension of the students to understand the modes (only in theoretical, practical, and both). The result is shown by the pie diagram in Figure 3.

The diagram shows that the Music student's understanding on the modes is dominated by the theoretical knowledge $58.06 \%$, followed by theoretical and practical knowledge $32.26 \%$, and practical knowledge $9.68 \%$. The mapping by the programs is shown by the bar chart in Figure 4.

The bar chart shows that the details of students who understand the modes by theory only come from the Bachelor Program of Music at 25.81\%, followed by Bachelor Program of Music Pedagogy at $22.58 \%$, and Vocational Program of Music Performance at $9.68 \%$. Students who understand the modes both theory and practice come from the Bachelor Program of Music at $19.35 \%$, followed by Bachelor Program of Music Composition

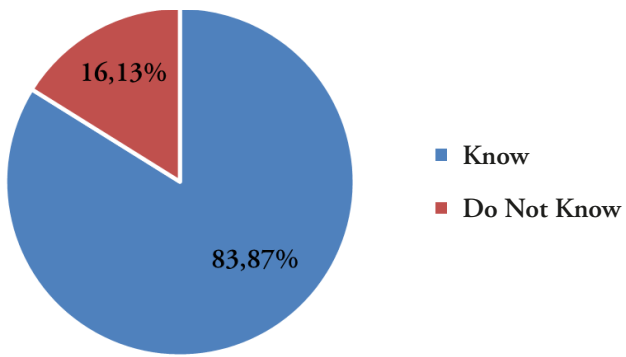

Figure 1: The Modes Knowledge of Music Department Students of Institut Seni Indonesia Yogyakarta.

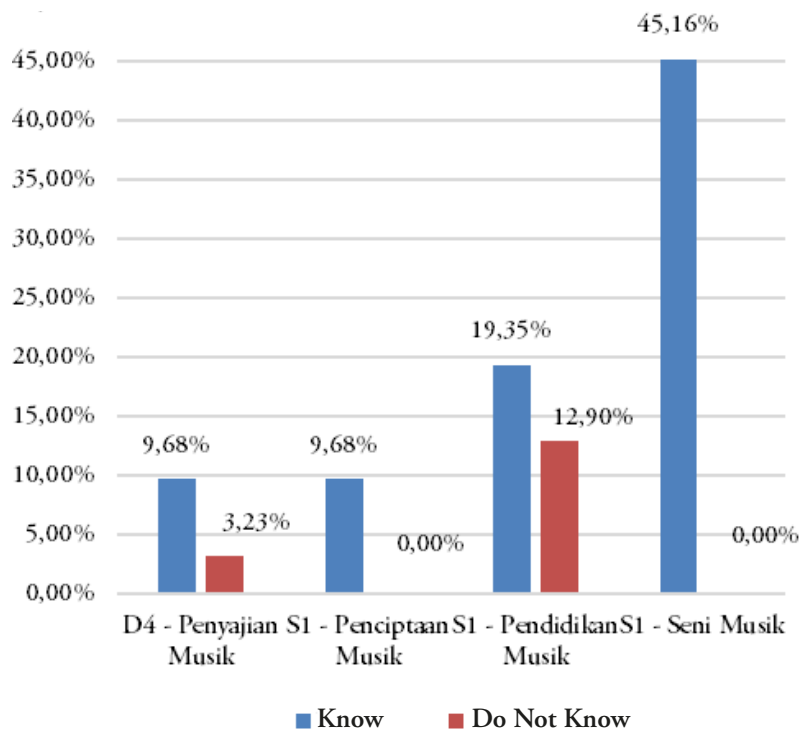

Figure 2: Data on Modes Knowledge of the Four Programs in Music Department.

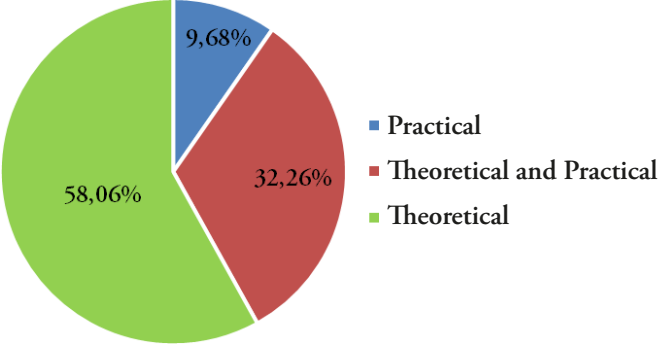

Figure 3: The Modes Understanding of Music Department Student.

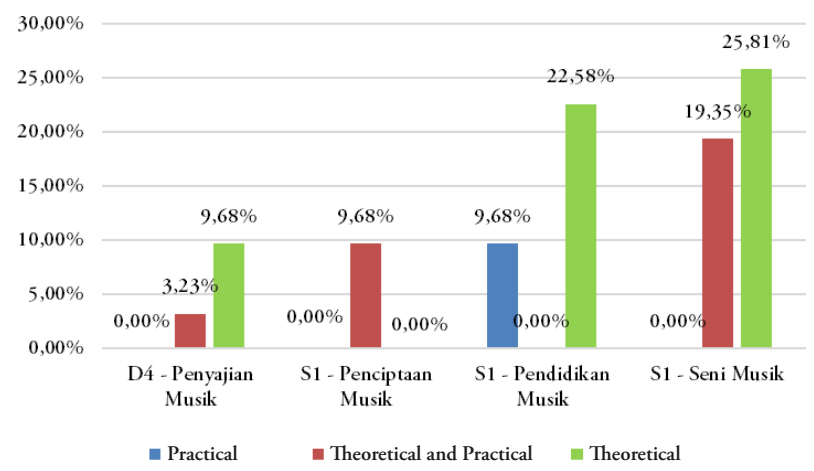

Figure 4: The Mapping of the Four Programs in Music Department Student's on the Understanding of Modes.

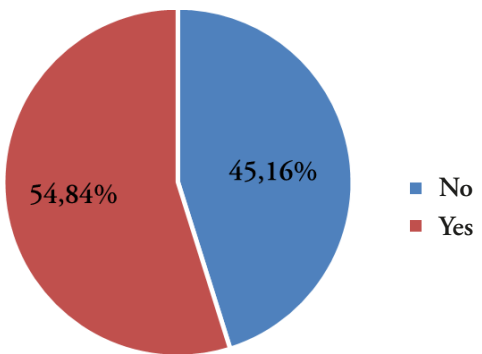

Figure 5: The Modes of the Music Department's hearing ability.

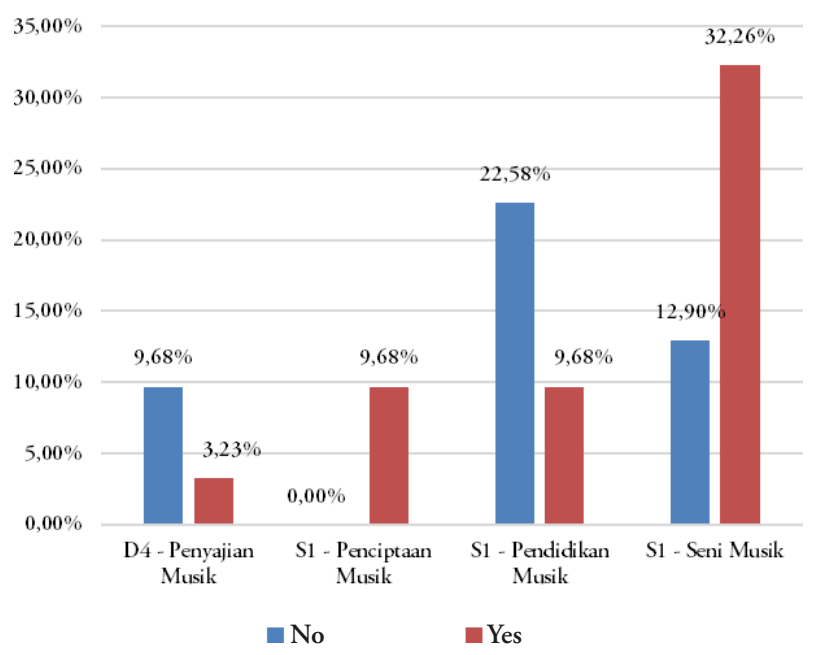

Figure 6: The Modes Indentifying of the Four Programs in Music Department Students. 
at $9.68 \%$, and Vocational Program of Music Performance at $3.23 \%$. Students with practical understanding only come from S1-Pendidikan Musik at $9.68 \%$. From the three parameters above, the understanding of Music Department Students is continued by collecting data about the hearing ability of Music Department Students, Institut Seni Indonesia Yogyakarta by played the musical works containing the modes. The result of this exploration is representated by the pie diagram in Figure 5. Of $54.84 \%$ students of Music Department is able to identify the modes in the musical works containing the modes, and of $45.16 \%$ is unable to identify it. The breaking down data based on the programs is representated by the bar chart in Figure 6. Music students who are unable to identify the modes come from Bachelor Program of Music Pedagogy at $22.58 \%$, followed by Bachelor Program of Music at $12.90 \%$, and Vocational Program of Music Performance at 9, 68\%.

\section{Conclusions}

By obtaining the data and analyzing the research result, it shows the modes identification of the 2015 and 2016 students of Music Department, Institut Seni Indonesia Yogyakarta. It is concluded that the modes identification is dominated by students who know about the modes, but their knowledge is dominated by theoretical knowledge only. Many of the 2015 and 2016 music students only know the modes by theoretical only, almost half of the 2015 and 2016 music students have not been able to identify the modes when playing the musical works which contain the modes. From the results of this research, the researchers suggest that the knowledge and understanding in modes identification need to be improved in all study programs, due to many numbers of musical compositions which contain modes todays.

\section{References}

An, K. (2019). A Pedagogical Guide for Teaching Diatonic Modality in the College Music Theory Curriculum. Ball State University, 1. Awwaabiin, S. (2021). Penelitian Kuantitatif:
Pengertian, Tujuan, Jenis-Jenis, dan Langkah Melakukannya. https://penerbitdeepublish. com/penelitian-kuantitatif/

Benward, B. (1989). Work Book in Ear Training. rown Company Publisher.

Birson, A. M., \& Erdoğdular, A. (2021). Understanding Turkish Classical Makam: Identifying Modes Through Characteristic Melodies. The Society for Music Theory Videocast Journal, 7(5).

Bostwick, J., Seror, G. A., \& Neill, W. T. (2018). Tonality Without StructureUsing Drones to Induce Modes and Convey Moods. Music Perception, 36(2), 243-249.

Hidayat, N., Lumbantoruan, J., \& Putra, I. E. D. (2018). Pengaruh Mata Kuliah Solfegio terhadap Kemampuan Transkripsi Mahasiswa Jurusan Sendratasik FBS UNP Angkatan 2015. Jurnal Sendratasik, 7(1), 41-51.

McNeill, R. J. (2002). Sejarah Musik 1 (2nd ed.). Gunung Mulia.

Nassaji, H. (2015). Qualitative and Descriptive Research: Data Type Versus Data Analysis: Language Teaching Research, 19(2), 129-132.

Sanchez, L. A. (2018). Polymodal Diatonicism in José Pablo Moncayo's Tierra de Temporal. Texas Tech University.

Stein, L. (1979). Structure and Style: The Study and Analysis of Musical Forms (Expanded). Warner Bros.

Sugiyono. (2017). Metode Penelitian Kuantitatif, Kualitatif, dan R\&D. Alfabeta.

Sulasmono, P. (2013). Peningkatan Kemampuan Vokal melalui Metode Solfegio. HarmoniaJournal of Arts Research and Education, 13(1). https://doi.org/10.15294/harmonia. v13i1.2532

Susani, P., \& Antokoletz, E. (2012). Music and Twentieth-Century Tonality: Harmonic Progression Based on Modality and the Interval Cycles. In Routledge.

Terefenko, D. (2017). Jazz Theory. In Routledge (2nd ed.). Routledge.

Torres, C. S. de. (2021). Musical Thought in Ancient Greece : Early Music SeattleEarly Music Seattle.

Veres, J. (2017). Modality - Resurgence of Musical Thinking. 1. 